\title{
12 Noon, Black Rock City
}

\author{
GRAHAM ST JOHN \\ UNIVERSITY OF REGINA, UNIVERSITY OF QUEENSLAND
}

from

the

floor

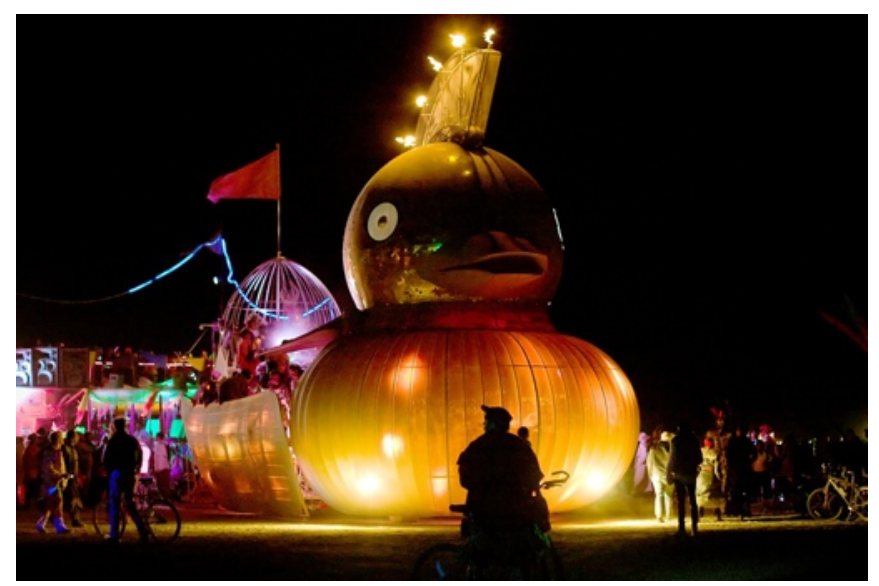

Disco Duck. Photo by Dave Le www.flickr.com/photos/splatworldwide/2825819212

It was a remarkable failure. My most impossible objective: to do The Man in a day.

Yes, that was the plan. Mounting pressures and misfortune back in the world (a new job approaching, a lost suitcase care of United Airlines and other miscellaneous matters), forced my decision to attend the week-long Burning Man festival in Nevada's Black Rock Desert for one day only.

Good thing, I thought, that my friend Seth was driving up on Wednesday night with the intention of departing by noon Friday (i.e. about thirty hours after our eventual arrival inside the festival at 4:30 AM Thursday). Seth would return to San Francisco to catch a flight to his mate's wedding. He was solid about this. I was resolute too... but Black Rock City has ways of tampering with your default settings, disrupting connections with the outside world, exposing sound intentions to immolation.

So there we were, making the six hour drive to Nevada out of the Haight in a hired Honda Element Zipcar - me, Seth, and his Mozilla workpal Arun. These guys are smart, explorationists, driven, dedicated tech-visionaries, not uncommon credentials for citizens of Black Rock City. We each had a bike strapped on at the rear - for Black Rock City, which this year would be populated by an excess of 50,000 Burners, is a metropolis of treadlies, the principal means of transport throughout the city grid, down the promenades and across the open playa. Stopping for supplies in Reno - the Emerald City of Nevada, all grandeur and illusion - Seth and I stocked up for our day long ride through the city of marvels and its environs (Arun was staying for the duration). 
We had a two hour wait in the queue upon arrival. Seth drove right into the left wing of the grid to our co-ordinates: the corner of $\mathrm{G}$ and 9:00. It was the Mootopia camp just opposite The Deep End, the popular dance camp completing their Burning Man adventure in 2008. Soon enough I vied for some sleep inside a dome belonging to the Root Society, out on the edge of the city on the corner of the Esplanade and 10:00. The dome featured a hive of comfortable Dr Seussian beds, no small hint of evolved Bohemia.

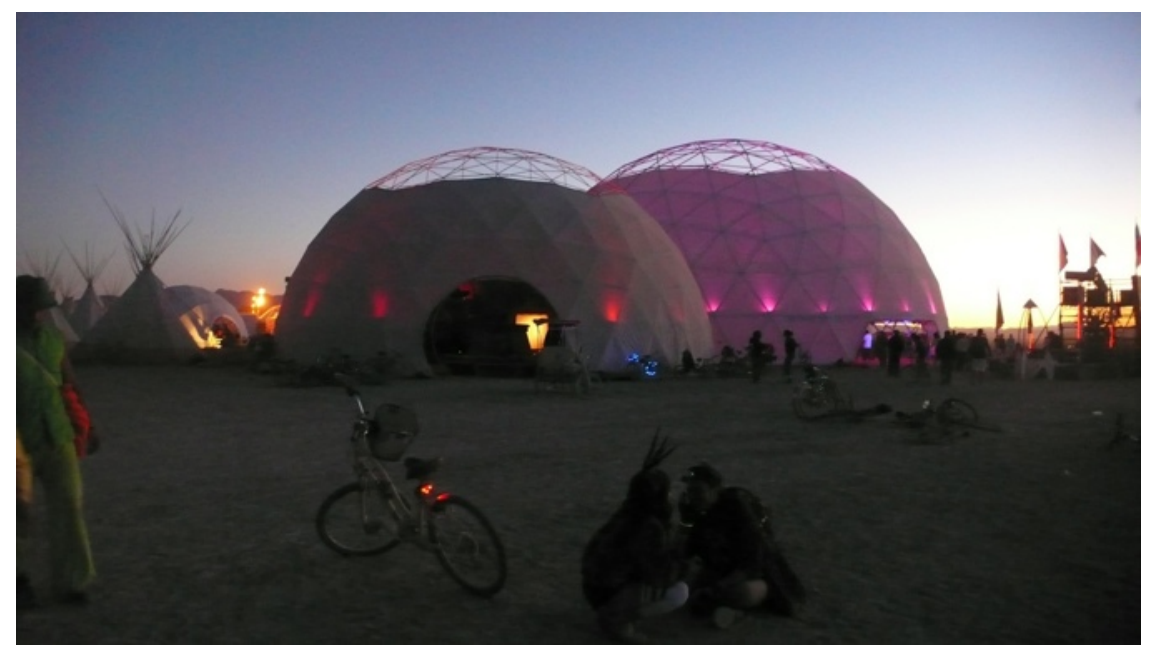

Root Society. Photo by Graham St John

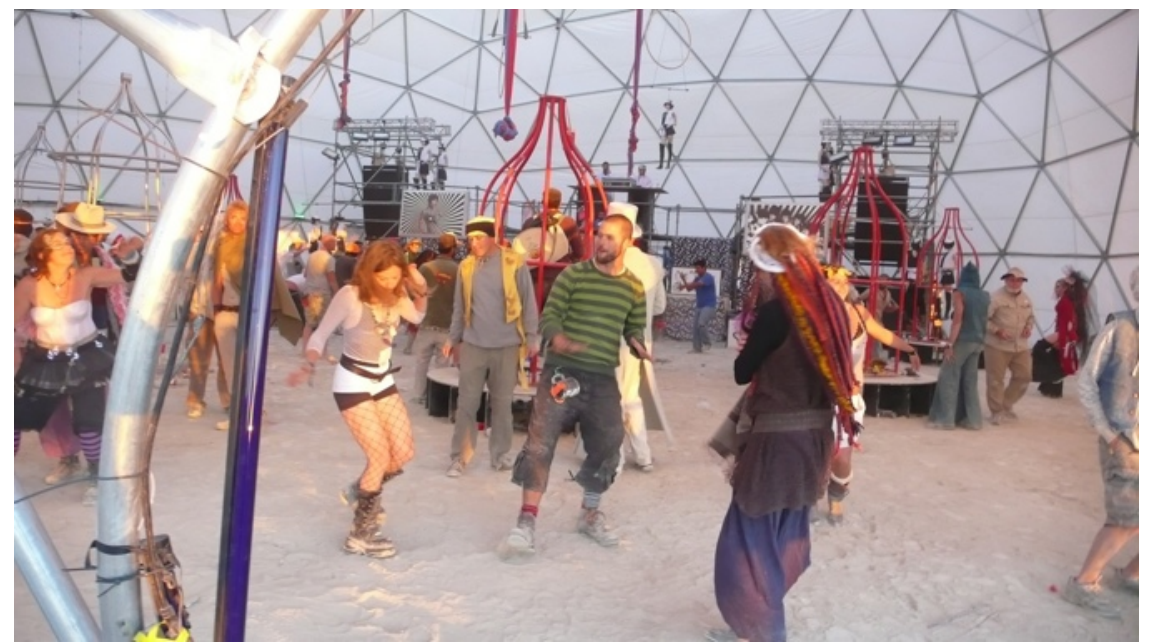

Root Society. Photo by Graham St John 


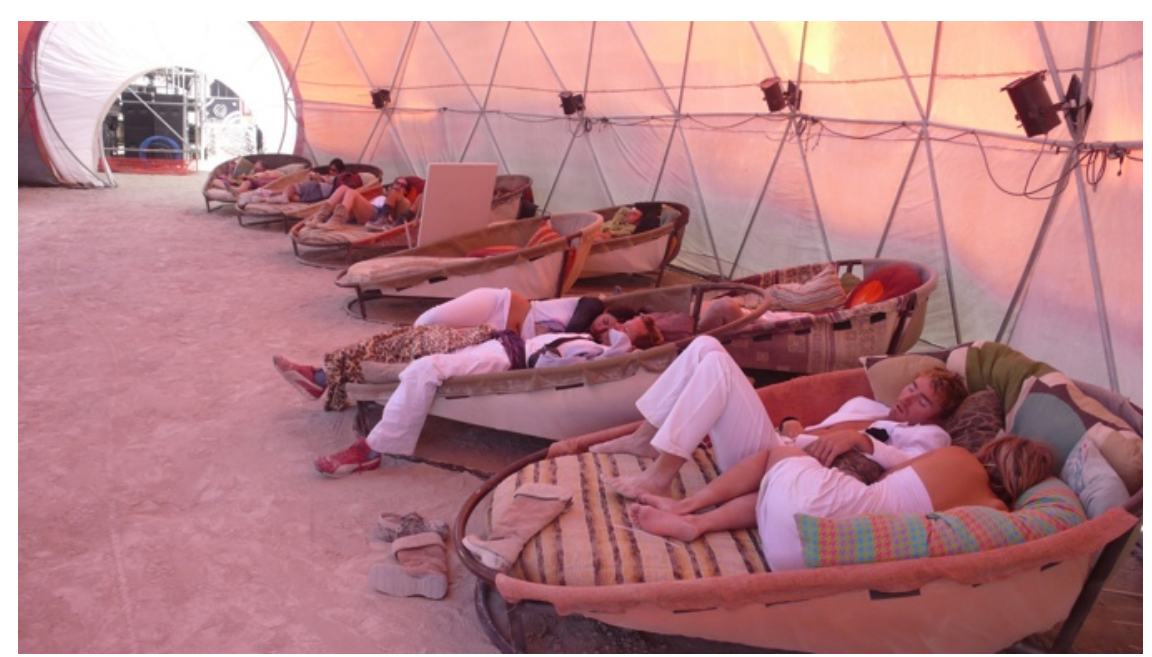

Root Society. Photo by Graham St John

With a linked entrance, a larger ninety foot dome featured the biggest indoor dance floor on the playa with a whomping sound system, clustered climbing positions for random displays of fleshy gesticulations, and hoisted rings and harnesses for nocturnal acrobatics. The place was a circus, and you the performer.

I would find myself performing there later that night, but not before humping my pedals around the city, biting the dust on the soft, uneven desert surface, seeking shade under the Man, positioned on a tower dedicated to diversity, one of the hallmarks, we're informed, of the American Dream, the theme of this year's event. If there's something that this event teaches us, it's a tolerance for difference, a hospitality unparalleled, a meaningfulness in the desert of the surreal that manifests in the act, and indeed the art, of giving.

We seek sanctuary at Center Camp under the intense midday sun, hovering for a while at the epicentre of the Burner scene, a vast ritual-theatre with no script. There are several performance platforms around this vast arena, but the stage boundaries are fuzzy as I hitch a ride in the moving spectacle of fury crotchless riding chaps, painted nipples and pink parasols. Having rung the virgin bell at the gate entrance only a few hours before, Arun announces that he is overwhelmed by sensory data. It appears as if he's had an empathogenic piñata broken over him and has merged with its contents. On his maiden Burn, wearing a fur-lined Moo outfit, he is already part of the performance. A stranger slips Baileys into my iced coffee. It courses through my veins as we saddle up and head out.

The day is filled with encounters - with new and old friends at camp Low Expectations part of the Blue Light District occupying a chock right on The Wheel at C and 5:30-6:00. 


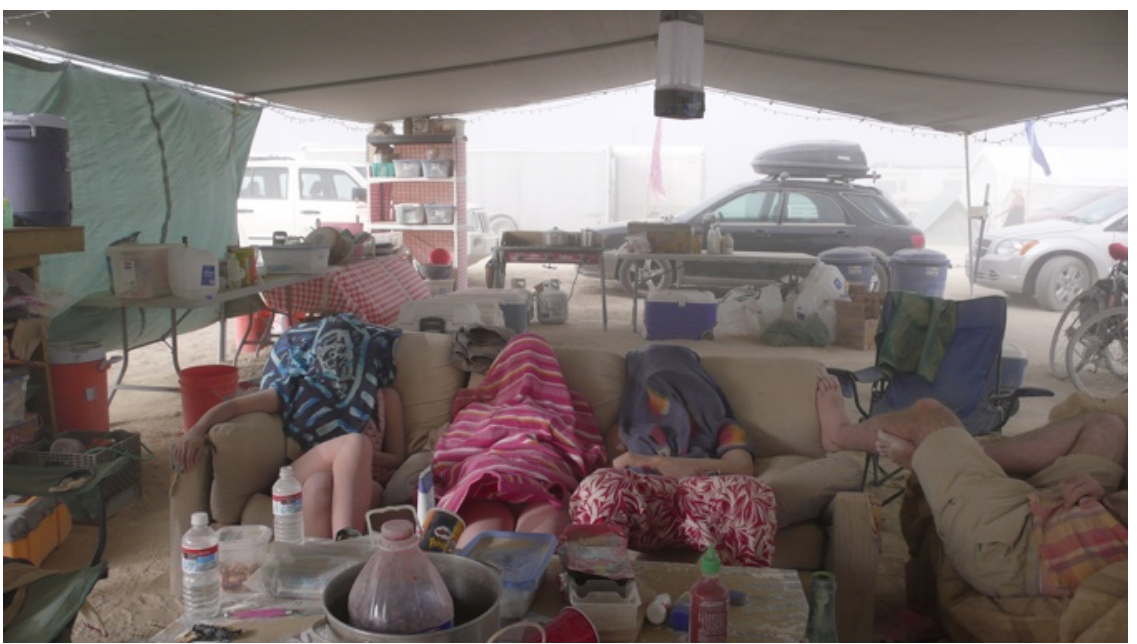

Camp Low Expectations. Photo by Graham St John

The camp could be called "The Comfortable Couch", or "Got Bacon", a lowkey affair whose hardcore geek mainstays have long assumed various volunteer roles at the event and in the Organisation. There's usually a few imbedded freakologists lurking around. I also meet Coach Ted, a man whose been Burning in absentia and finally made it home; the folks at Spock Mountain Laboratories with the scoop on "DJ Testitio"; Wonder Woman and other Mootopians; and ventured out into The Deep End...

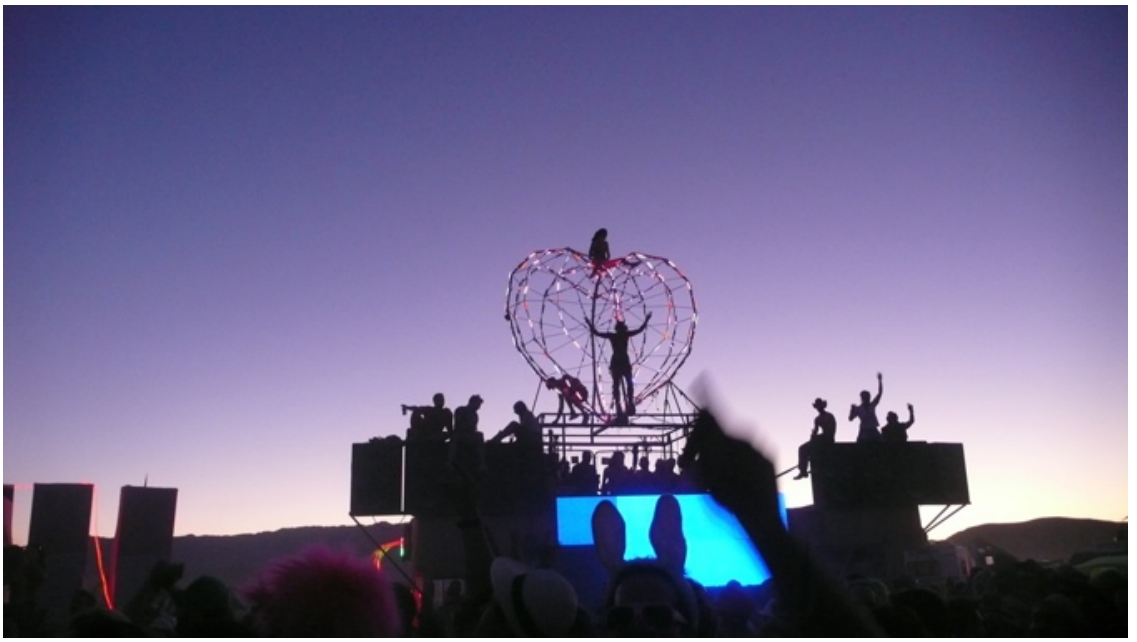

The Deep End. Photo by Graham St John

As night falls over Black Rock City, it explodes with a collective charge unparalleled anywhere on the planet. The city ordinance to "leave no trace" and the commitment to develop responsible energy conservation strategies conflicting and other times complementing the orgiastic desire to lay waste to one's personal and collective resources. After all we were Burners, caste to perform in a ritual-theatre of sacrifice, sophisticated yet primal. And so, after dusk, with enough inspiration to overpower mor- 
tality, we plough through the dune-ripples racing ahead of the spice worms who would intoxicate us with sleep, or worse... wakefulness. This was extreme partying, and we were the dosed-up denizens of deep playa.

Dismounting at the far terminus of the Esplanade at 2:00, I'd been riding the escalator all the way to the roof. But this was no smooth transit, with no predictable momentum, nor clear meaning. No certain arrival, and an even less certain departure. With its blinking mirages, fine dust white-outs, and blizzards of sensory impressions obfuscating clear directions, clarity and certitude are in short supply on the playa, a delirium that is translated into a style of music that plays havoc with predictability. Through broken polyrhythmic patterns, the festal distraction is embodied in the electro breakbeat, notorious for its derangement of repetition. Aural decay, a breakdown of structure, and an arse-shifting funk.

A spectre appears out of the desert night... it's me... With fellow night rider, Seth, who wears a plastic gold \$ necklace, and Arun, aglow in Mootopian fur on an ELwired steed, we dismount in the open space of the Opulent Temple, an art and sound camp in its sixth year, built on the perennial shores of breakdown and release.

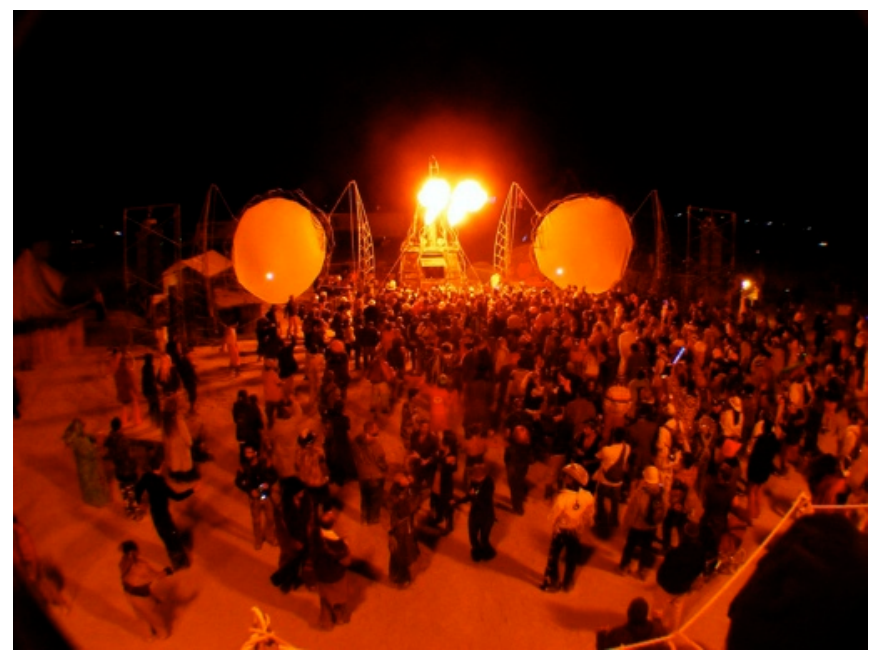

Opulent Temple. Photo by Stefan Werner

It was around midmorning and Lee Coombs was coming on. Now here's a guy who knows how to shift arse, and when it comes to finely sculpted and well-cropped playabutt, this is not, by anyone's countenance, a standard operation. Coombs is a master of the build, accumulating all that tension, obtaining critical thresholds, until the electronic floodgates are finally opened and the playa-massive - the fleshive - is permitted to erupt with abandon. At the Opulent Temple, you know that moment has arrived as flames blast out from the DJ booth, a chamber that is part steampunk time machine and alchemist's laboratory. 


\section{Mutate and Survive}

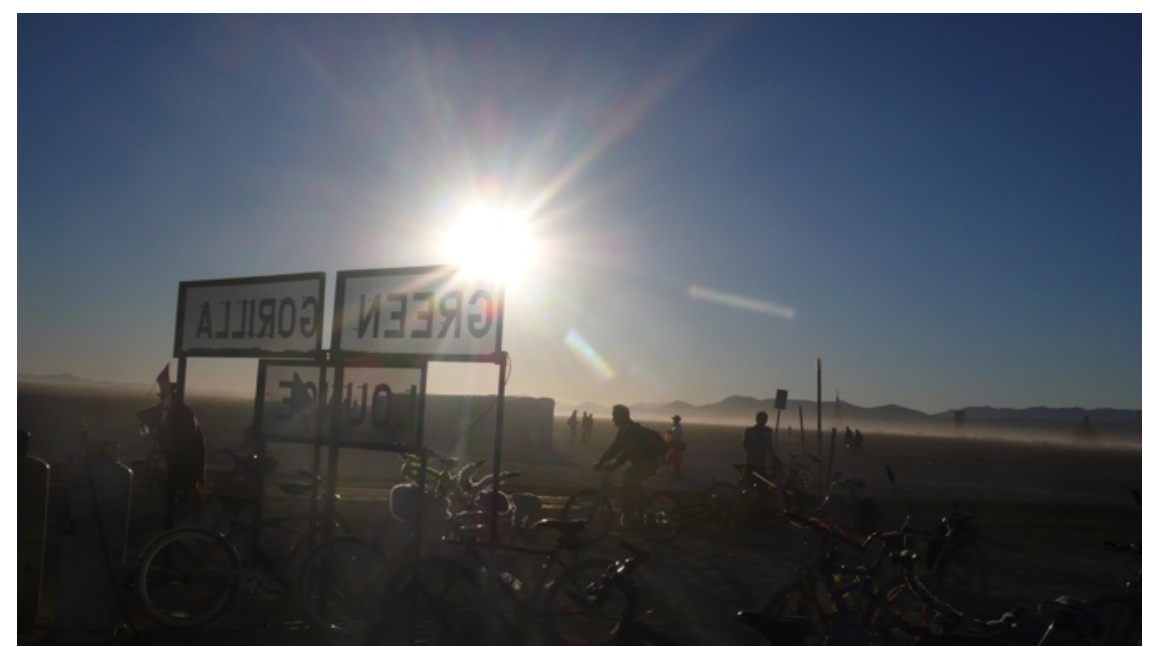

Green Gorilla Lounge. Photo by Graham St John

Hours passed and it seems like I had danced across time and space ... into the subjunctive realm. Near sunrise over the other side of the Man above 10:00, I stumbled into the dome of the Root Society. It was like morning assembly in the asylum, with duo 313 tronic animating the disturbance. As the golden disc arose in the east, I made contact with the folks at the Green Gorilla Lounge, hunkering down over the raw funk cooking in their dome. It was here that I made interception with an object words can hardly translate.

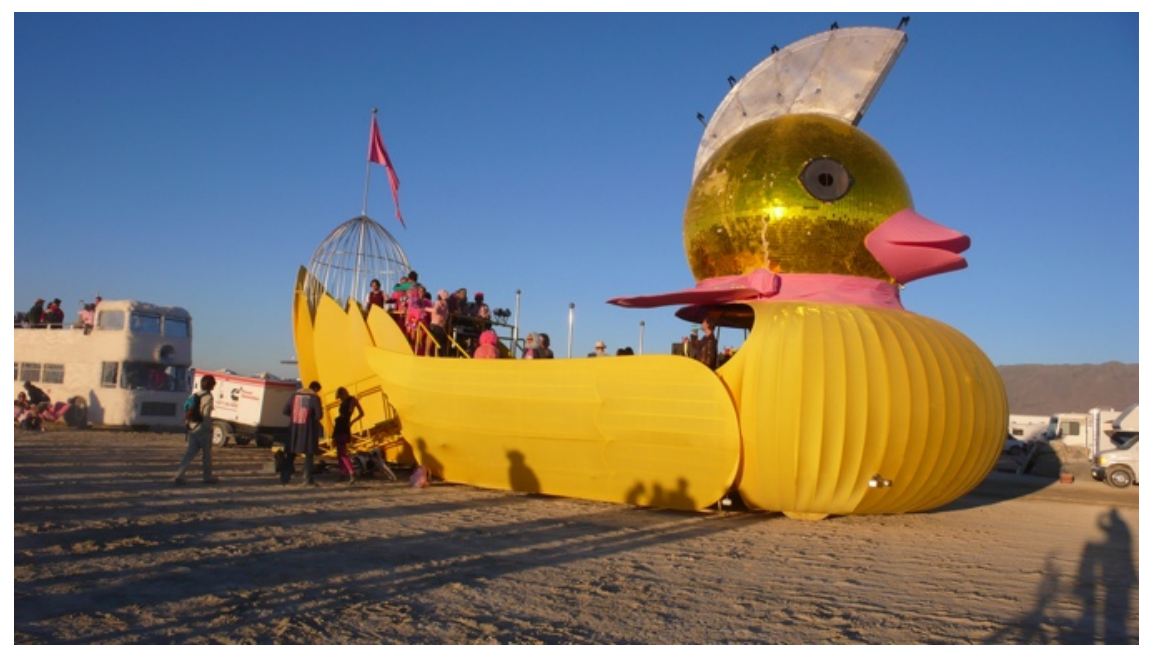

Disco Duck after dawn. Photo by Graham St John 
It was the most audacious sound art vehicle on the playa. A mobile three level club in the shape of a yellow bath-time duck, the Disco Duck had unloaded its weird human cargo to greet the rising sun. With an auxiliary vehicle (a fur-lined double-decker bus) stocked with an arsenal of champagne, and with the morning sunlight refracting off its golden glitterball head, the duck was exposed in all its splendor. After dusk, the giant duck with its green lasers for eyes and a fire-spitting mohawk, became integral to the nightworld at Burning Man.

http://www.flickr.com/photos/quikbeam/2824483573/in/pool-burningman Disco Duck video

Constructed upon an armoured amphibious assault vehicle, an instrument of warfare is reclaimed and transmuted into a pleasure machine. Although the amphibious vehicle lay hidden in its design, it is reminiscent of the reclamational work of legendary industrial-sculpture collective the Mutoid Waste Co., renowned for recruiting war machines for radical assaults on the senses. Throwing the first acid house warehouse raves in London at the old Coach Station and mutating the refuse of modern culture into the Marvelous, these salvage-situationists had been instrumental conspirators in London's reclamational sensibility. Throughout the mid to late 1980s, and into the 1990s, the Mutoids had been busy revivifying obsolescence and transforming forgotten landscapes into objects and sites of beauty, stirring those who came to witness, and dance, with a passion to make some noise. In London and across Europe, furnishing squatted buildings with anthropomorphic engines, mutated bike parts, transmuted MIG fighter jets, and raising subterranean spaces of difference where all became a spectacle to each other, they incited fellowship and inspired the imagination.

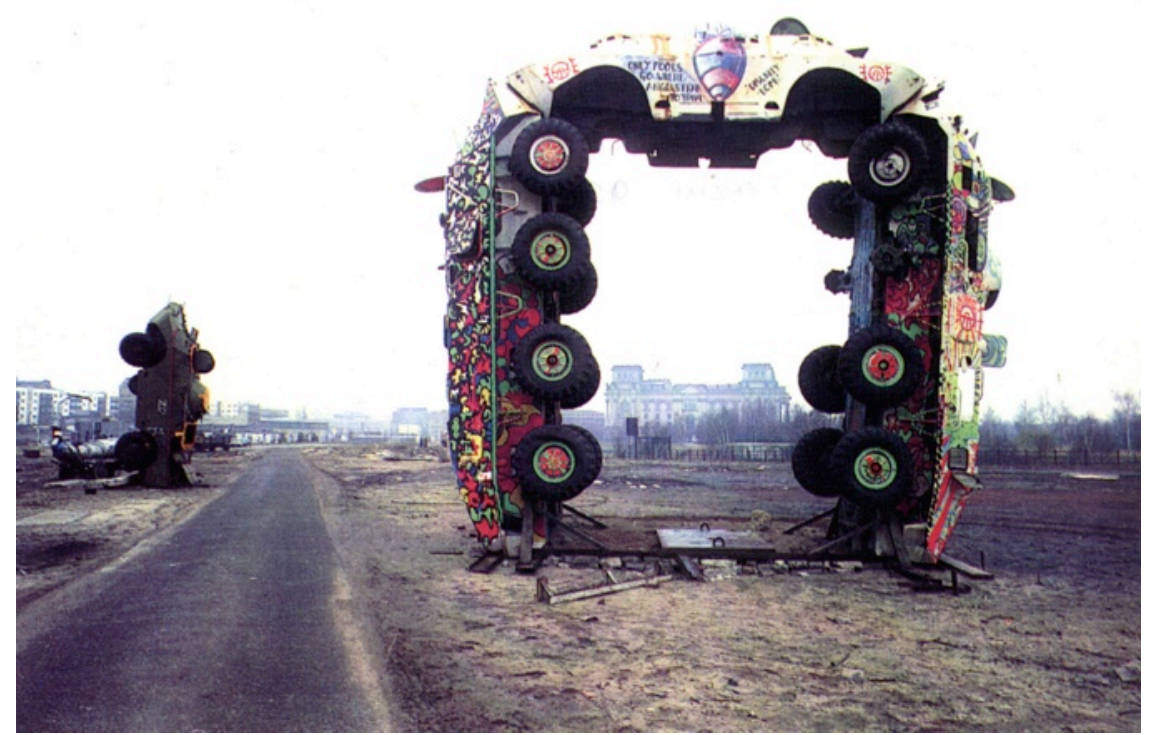

MWCo Tankhenge framing Rieschstaag Berlin 1992. Photo by Rene Menges 


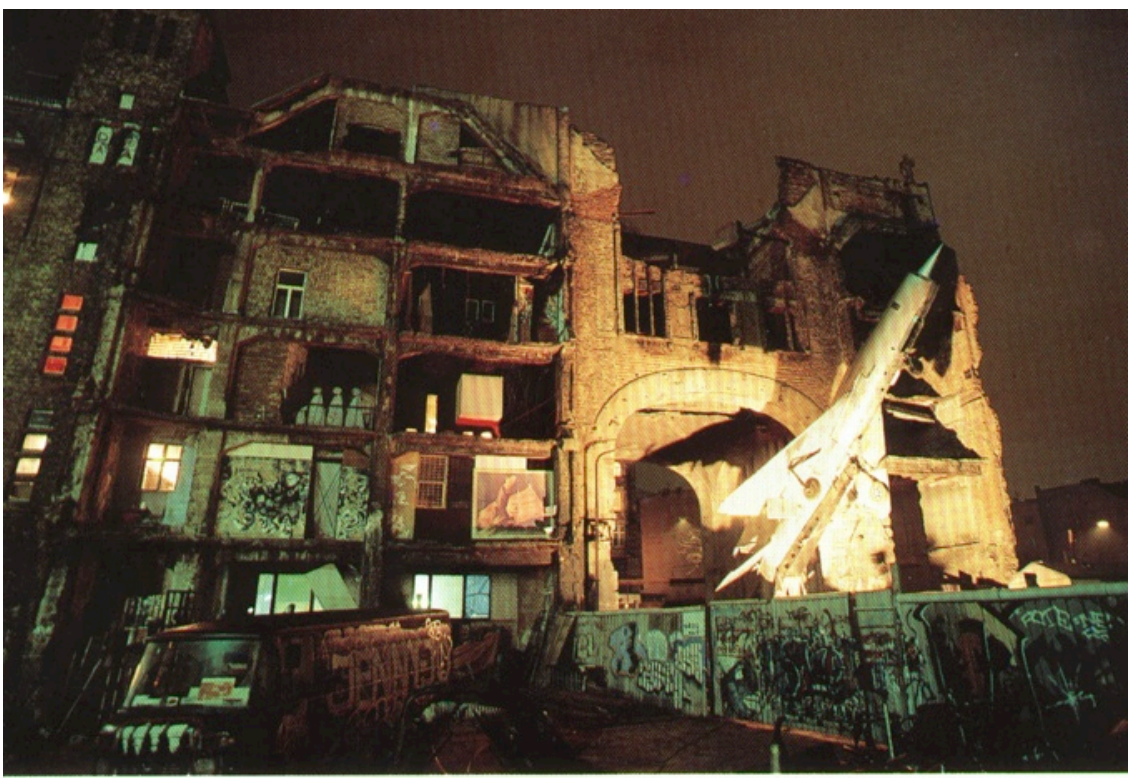

MWCo. Set for "Blast Off 94", Tachelles Berlin. Photo by Rene Menges

In Australia, Robin Mutoid Cooke's Mutonia Sculpture Park, which includes Planehenge among other pieces, constitutes an important development in this recycladelic diaspora. This is important to mention not least since last Winter Solstice, Mutonia, near Marree in outback South Australia, hosted the annual Mighty Burning Demon festival, a small gathering in which the burning of an anthropomorphic figure transpires. Sound familiar?

The MWCo were building "art cars" before the Man was first set aflame on Baker Beach in the mid 1980s. You can see video compilations of early Mutoid work on Youtube at $<$ http://www.youtube.com/watch?v=amZltDRlico\&feature=related $>-$ note the "zombie beat" elicited by the Mutoid band presaging an electronic soundtrack at parties. And Robin Mutoid's lens on the MWCo can be found in his chapter in a book I edited FreeNRG: Notes From the Edge of the Dancefloor (Common Ground: 2001). $<$ http://undergrowth.org/freenrg notes from the edge of the dancefloor $>$.

With the prospect of nuclear Armageddon shaping their artifice, the Mutoids developed a near obsession with a post-apocalyptic Mad Max aesthetic. "Mutate and Survive" - a rephrasing of the Campaign for Nuclear Disarmament slogan "Protest and Survive" - became the Mutoid mantra conveying dissatisfaction with conventional forms of protest which they thought ineffectual, and which would emblematize their own brand of resistance to the nuclear age.

All of this is not remote from Burning Man. For one thing, The Death Guild, with their Thunderdome arena and fleet of vehicles at least in part inspired by the Road Warrior, have long been integral to the event. The Death Guild illustrate that, out here, almost anyone can be a post-apocalyptic cult hero. For another thing, MWCo artists landed at Burning Man in force this year with their head-turning motorised animatronic fire-breathing stallion (built from a V8 powered $4 \times 4$ and classic Chevrolet and Cadillac parts) and covered wagon with sound system and decks, Spaghetti West 10, and a pair of dinosaur-like mechanical beasts: the Dino-Dumper and the Clamp-O-Saurus. 


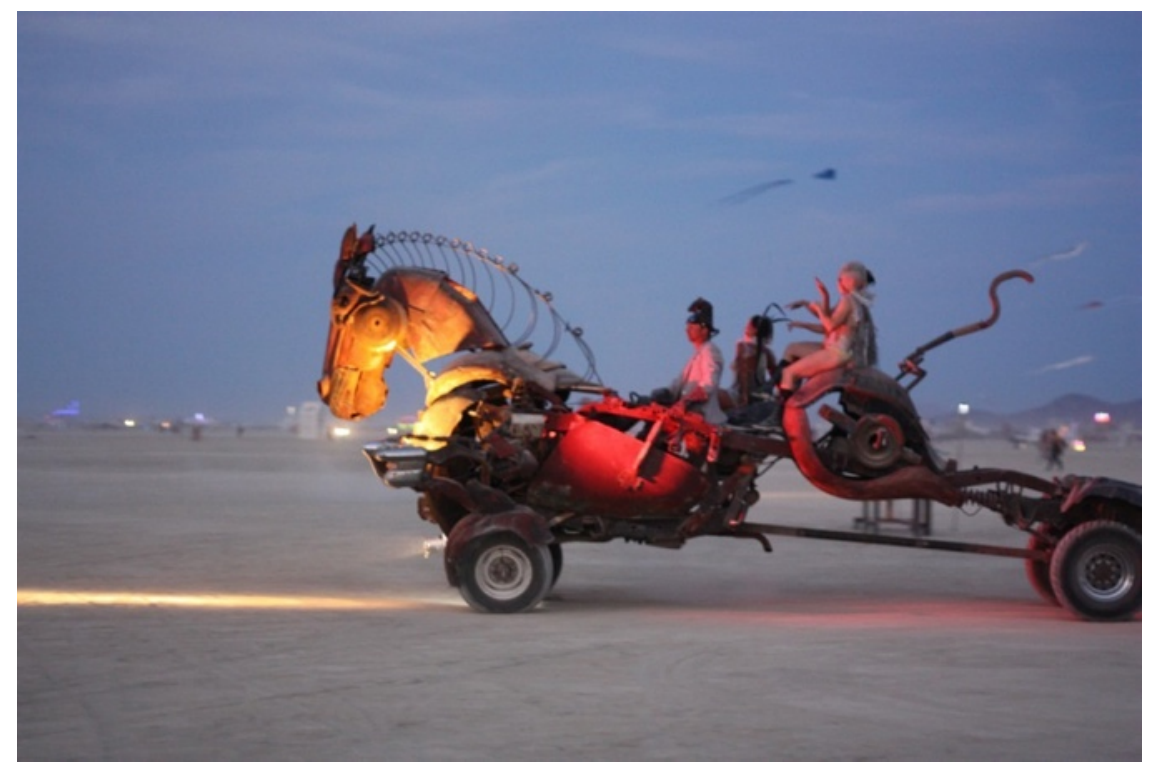

Mutoid Waste Co's Spaghetti West 10. Photo by Spolombian

But I digress. It was now Friday, approaching noon. Apart from a couple of dozey hours on a mattress in the shade at the Deep End, I'd hardly slept. At this point the reasoning behind my departure was occulted by a looming white-out, my plans drifting rapidly out of view. Twenty-four hours in the desert and I was like Sergeant Howie, the archetype of order and organisation whose convictions made him the prime candidate for incineration in The Wickerman.

I rode downtown to camp Low Expectations to say goodbye to my friends. I arrive there and within minutes I'm drawing from a bottle of Tabu Dry. It was my friend Michael's parting gesture. Soon I'd be on the road back to California.

Just then, Jessica says, "why don't you stay."

"I can't."

"Why not?"

I was stumped. I couldn't rightly recall. But then I remembered something. I didn't have water, much food, nor a tent, blanket, supplies for another 4 days in the desert. I'd prepared for one day, as I needed to get back to the city... for something.

"But we have more than enough water, food. Even a tent and a blanket..."

I was reclining on a tres comfortable couch in the middle of the desert glissading on absinthe, surrounded by 50,000 fellow pilgrims within a two-mile radius. With each word she spoke I had fewer reasons to leave, until I was finally checkmated: "we can give you a ride back on the bus".

What had I been thinking? Hadn't I realised I'd get caught in this momentum, this open-ended potlatch of epic proportions, this vast canvas the significance of which lies in the relationships one forms through shared consumption in extreme conditions? Out here, in one of the most physically inhospitable landscapes in the country, transformed over a week into one of the more socially receptive environments a human can know, I was like the guy who once turned up at the entrance naked as an experiment to learn if and how he could survive. My failure to leave and his successful survival are strangely connected, if by nothing other than the compelling gift. 
I would soon cycle back across the city to break the news to Seth - himself on schedule to bail at noon. "Congratulations", he smiles, handing me his remaining supplies, "you failed".

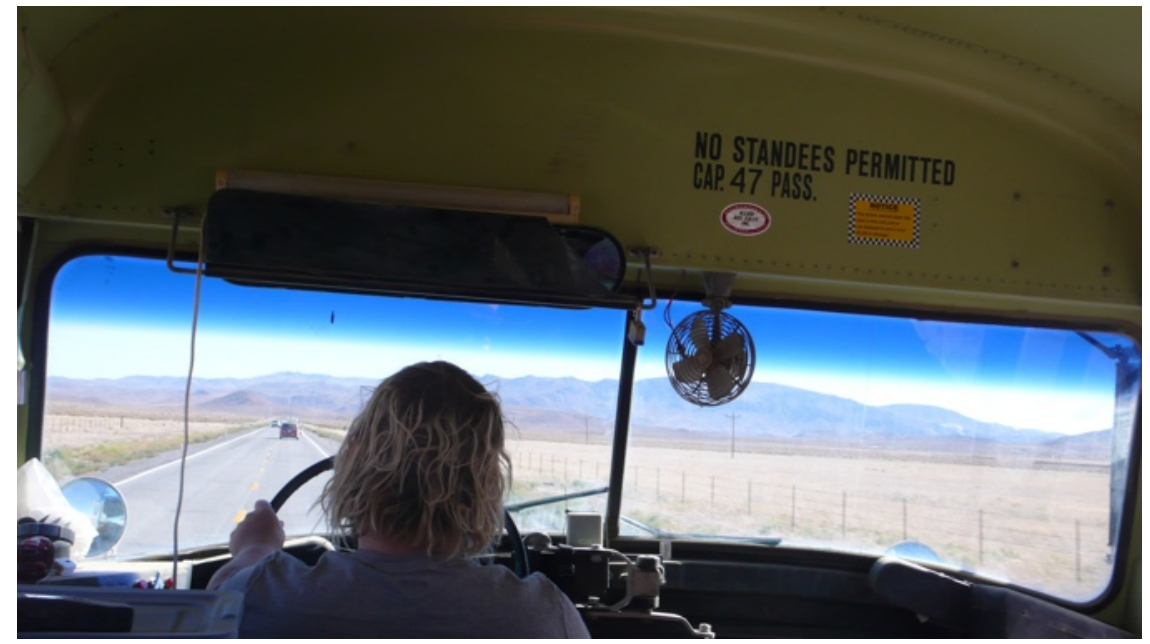

Exodus. Photo by Graham St John

\section{Acknowledgements}

Thanks to crew at Low Expectations who made this short story Odyssean, including Seth, Arun, Paulie, Coach Ted, Lee Coombs, the super-cockers, and all those otherselves who Burn.

\section{Author Biography}

Graham St John is a Research Associate at the Centre for Critical and Cultural Studies at the University of Queensland and was recently a Postdoctoral Research Fellow in Interactive Media and Performance at the University of Regina, Saskatchewan. His latest book Technomad: Global Raving Countercultures (Equinox) will be published in September 2009. He is the Executive Editor of Dancecult. See: www.edgecentral.net 